\title{
Vertical distribution of zooplankton biomass and ichthyoplankton density during an annual cycle on the continental shelf of the southern Gulf of Mexico
}

\author{
Distribución vertical de la biomasa zooplanctónica y densidad ictioplanctónica durante \\ un ciclo anual en la plataforma continental del sur del Golfo de México \\ María de la Luz Espinosa-Fuentes ${ }^{1 *}$, César Flores-Coto ${ }^{1}$, Laura Sanvicente-Añorve ${ }^{1}$ \\ and Faustino Zavala-García ${ }^{1}$ \\ ${ }^{1}$ Laboratorio de Zooplancton, Instituto de Ciencias del Mar y Limnología,Universidad Nacional Autónoma de México. \\ A. P. 70-305, 04510 México, D. F. México \\ *marilu@cmarl.unam.mx
}

\begin{abstract}
Resumen.- Se analizó estacionalmente la biomasa zooplanctónica (BZ) y la densidad ictioplanctónica (DI) en la columna de agua sobre la plataforma continental del sur del Golfo de México, para determinar sus patrones de distribución vertical y establecer si existe una relación entre ambos componentes. Se muestrearon cinco niveles de profundidad: 0-6 m, 6-12 m, 12-18 m, 45-55 m y 95-105 m. El patrón de distribución vertical de la BZ y de la DI fue similar en todas las épocas de muestreo, con la mayor concentración de organismos en los niveles superficiales y la más baja en los niveles más profundos. Estos resultados sugieren que la columna de agua en el área de estudio puede estar dividida en una capa superficial ( 0 a $18 \mathrm{~m}$ ) y una capa profunda (45 a 100 m) y que las diferencias estacionales pueden ser atribuidas a los procesos de mezcla. Esta diferencia entre las capas superficiales y las profundas ocurre porque, en general, las capas superficiales de la columna de agua son las más productivas. La relación entre la $\mathrm{BZ}$ y la DI fue positiva y significativa (ANCOVA, $P<0,05$ ) a través de las épocas de muestreo y en la mayoría de las profundidades probablemente porque el ciclo de producción es continuo en el sur del Golfo de México como sucede en áreas tropicales y subtropicales, manteniendo la disponibilidad de alimento y consecuentemente, la relación depredador-presa. La relación BZ y DI en la columna de agua es afectada principalmente por la variación estacional de las descargas de agua continental y el proceso de mezcla.
\end{abstract}

Palabras clave: Capa de mezcla, descargas de agua continental, estratificación, relación zooplancton-ictioplancton

\section{Introduction}

One of the most productive areas in the Gulf of Mexico is the Bay of Campeche, as it receives great volumes of continental water. The large fisheries based on pelagic fish and shrimp are a reflection of the high biological productivity of the area. This has prompted a number of studies of secondary production in this ecosystem

\begin{abstract}
Seasonal zooplankton biomass (ZB) and ichthyoplankton density (ID) in the water column on the continental shelf of the southern Gulf of Mexico were analyzed to determine their vertical distribution patterns and assess if there is a relationship between both components. Five depth levels were sampled: 0-6, 6-12, 12-18, 45-55 and 95-105 m. The vertical distribution patterns of ZB and ID were similar for all sampling seasons, with the greatest concentration of organisms in the upper levels and the lowest at deeper levels. These results suggest that the water column in the study area may be divided into a surface layer $(0-18 \mathrm{~m})$ and a deep layer (45-100 m), and seasonal differences may be attributed to mixing processes. The difference between the surface and the deep layers occurs because, in general, the upper layer is the most productive sector of the water column. The relationship between $\mathrm{ZB}$ and ID in the water column was positive and significant (ANCOVA, $P<0.05$ ) throughout the sampling seasons for most depths, probably because the production cycle is continuous in the southern Gulf of Mexico, as is common in tropical and subtropical areas, and it maintains the availability of food, and consequently the predator-prey relationships. The relationship between the $\mathrm{ZB}$ and the ID in the water column is mainly affected by the seasonal variations in the continental water discharges and the mixing processes.
\end{abstract}

Key words: Continental water discharges, mixing layer, stratification, zooplankton-ichthyoplankton relationship

(Flores-Coto et al. 1988, Gasca et al. 1995, Salas de León et al. 1998) and the ichthyoplankton community (FloresCoto et al. 1988, Flores-Coto \& Ordóñez-López 1991, Flores-Coto et al. 1993, Sanvicente-Añorve et al. 1998, Flores-Coto et al. 2000).

Most of these studies only address horizontal mesoscale variations, while knowledge on the vertical 
distribution of zooplankton and ichthyoplankton in the southern Gulf of Mexico is scarce (Flores-Coto et al. 1999, 2001, Espinosa-Fuentes \& Flores-Coto 2004).

Knowledge of the vertical distribution patterns of zooplankton biomass and ichthyoplankton density is important to understand ecological processes and to evaluate the abundance of these communities in the region. Studies performed in other areas demonstrate that variations in the structure of the water column affect the spatial and temporal distribution of zooplankton and ichthyoplankton (Ahlstrom 1959, Loeb \& Nichols 1984, Munk et al. 1989, Davis et al. 1990, Sclafani et al. 1993, Boehlert \& Mundy 1994).

In spite of the high biological productivity in the Bay of Campeche and the ecological importance of zooplankton and ichthyoplankton, the relationship between both components has not been addressed.

Considering that production cycles in the southern Gulf of Mexico are continuous and that ichthyoplankton depends on zooplankton biomass for food, we hypothesized that the vertical distribution of ichthyoplankton is synchronous with the biomass distribution of zooplankton, and that they have a positive relationship throughout the water column.

The objectives of this study were to determine the vertical distribution patterns of both zooplankton biomass (ZB) and ichthyoplankton density (ID), and to assess the relationship between $\mathrm{ZB}$ and ID at different water depths, and how it varies according to the physical environment throughout an annual cycle.

\section{Material and methods}

The study area is located in neritic waters of the southern Gulf of Mexico, between $18^{\circ}$ and $20^{\circ} \mathrm{N}$ and between $91^{\circ}$ and $94^{\circ} \mathrm{W}$. Twenty-two sampling stations were distributed along four transects perpendicular to the coast, located off the main fluvio-lagoon systems of the region (Fig. 1). Sampling was carried out in May 21-30 (spring), August 19-29 (summer) and November 17-27 (autumn) of 1994, and in February 7-17 (winter) of 1995, aboard

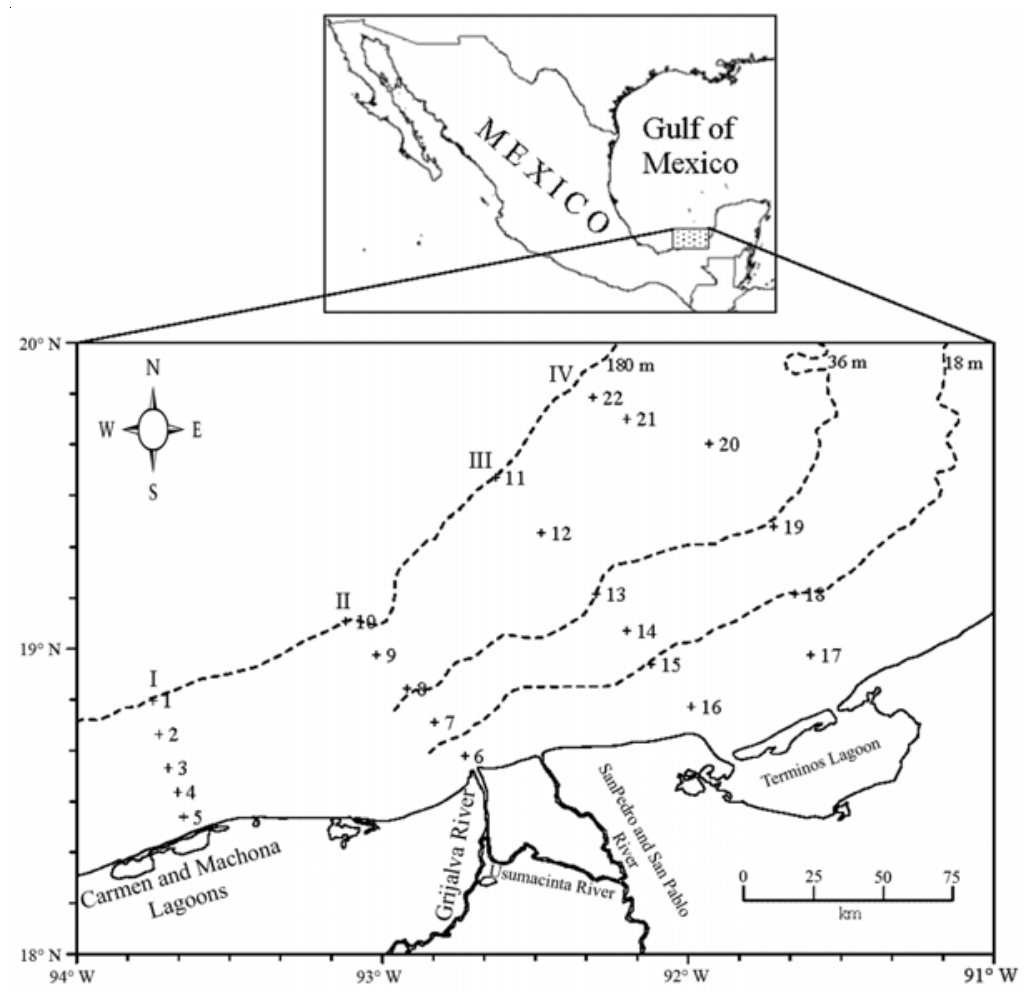

Figure 1

\section{Study area and location of sampling stations in the southern Gulf of Mexico}

Área de estudio y localización de estaciones de muestreo en el sur del Golfo de México 
the R/V Justo Sierra. Samples were collected with a multiple opening-closing plankton net system with a 505 $\mu \mathrm{m}$ mesh and a $75 \mathrm{~cm}$ diameter mouth. Five depth levels (level 1: 0-6 m; level 2: 6-12 m; level 3: 12-18 m; level 4: 45-55 m, level 5: 95-105 m) were sampled at each station. Flowmeters were attached to each net in order to determine water volume. Plankton samples were fixed with 4\% formalin. Zooplankton biomass was determined as wet weight, except for the big jellied organisms, and each sample was placed in a suction filter system in order to eliminate interstitial water (Zavala-García \& FloresCoto 1989). Ichthyoplankton density (ID) was standardized as number of larvae $100 \mathrm{~m}^{3}$ :

$$
\text { ID }=\frac{\text { Num. of larvae }}{\text { Filtered Volume }}
$$

Differences in ZB and ID distributions regarding daynight variations were established with a one-way ANOVA for the four cruises and the different sampling levels. The homocedasticity of ZB and ID data was determined with the test of Levene (Levene 1960). The data were logtransformed $[\ln (x+1)]$ as the biomass and the ichthyoplankton density did not present a normal distribution.

The relationship between ZB and ID at each sampling level for the different study periods was evaluated using an analysis of covariance (ANCOVA) where ID was the dependent variable, $\mathrm{ZB}$ the covariant, and the sampling level was represented as a categorical variable. A Pearson's correlation analysis was applied to the data to evaluate the correlation between ZB and ID at each sampling level and to obtain the statistical significance (Zar, 1996).

The influence of the environmental variables on the relationship between $\mathrm{ZB}$ and ID at each sampling level during the different study periods was evaluated with a Multiple Regression Analysis (MRA). The better adjustment between the dependent variable (ID) and the independent variables (ZB, depth, temperature, salinity, vertical salinity gradient and potential energy anomaly) for each sampling season was obtained applying a General Linear Model (GLM) to determine the effects of the independent variables. The stratification degree of the water column was estimated calculating the potential energy anomaly or $\varphi$ parameter (Simpson et al. 1978):

$$
\varphi=\frac{1}{h} \int_{-h}^{0}(\rho-\bar{\rho}) g z d z \quad \text { with } \bar{\rho}=\frac{1}{h} \int_{-h}^{0} \rho(z) d z
$$

where $\mathrm{g}$ is the acceleration due to gravity $\left(9.82 \mathrm{~m} \mathrm{~s}^{-2}\right), \rho$ is the water density $\left(\mathrm{kg} \mathrm{m}^{-3}\right), \mathrm{h}$ is the water depth $(\mathrm{m})$, and $\mathrm{z}$ is the depth interval (m).

Continental water discharge was determined through the vertical salinity gradient.

$$
\mathrm{Gz}=-\frac{S 2-S 1}{\Delta z}
$$

where S1 and S2 are the salinities at the given points and $\Delta \mathrm{Z}$ is the distance between them.

\section{Results}

\section{Environmental variables}

Water temperature was homogeneous during May, August and November 1994 from the surface to $18 \mathrm{~m}$ depth (levels 1,2 and 3), with values of 27.8 to $28.8^{\circ} \mathrm{C}$, and it varied from 19.3 to $24.9^{\circ} \mathrm{C}$ at deeper levels (45-105 m). In February 1995, temperature was homogeneous $\left(\sim 24^{\circ} \mathrm{C}\right)$ from the surface to $70 \mathrm{~m}$ depth, after which it decreased to $18.8^{\circ} \mathrm{C}$ from this depth down to $100 \mathrm{~m}$ (level 5) (Fig. 2).

There was a mixing layer from the surface to $30 \mathrm{~m}$ depth during May, August and November with $\varphi$ values $<20 \mathrm{~J} \mathrm{~m}^{-3}$. The $\varphi$ values increased in deeper waters to $>250$ $\mathrm{J} \mathrm{m}^{-3}$ at $100 \mathrm{~m}$, indicating a marked stratification. In February, the mixing layer reached $70 \mathrm{~m}$ with $\varphi<12 \mathrm{~J} \mathrm{~m}^{-3}$, and at 100 $\mathrm{m}$ the $\varphi$ value was $\sim 150 \mathrm{~J} \mathrm{~m}^{-3}$ (Fig. 2).

The effect of the continental water discharges on the study area were more evident in August and November, when the greatest value of the vertical salinity gradient was recorded between the surface and $18 \mathrm{~m}$ depth (Fig. 2).

\section{Vertical distribution of zooplankton biomass and ichthyoplankton density}

The vertical distribution of ZB and ID was similar throughout the seasons, with the greatest organism concentration in the upper levels (1,2 and 3) and the lowest in the deeper levels (4 and 5), regardless of the time of day.

Day-night variations in ZB and ID presented similar patterns during all sampling periods, with the highest values during the night and the lowest values during the day (Fig. 3).

During May, August and November, the higher concentration of ZB in the water column was observed at night in the surface levels $(0-18 \mathrm{~m})$, with the highest 

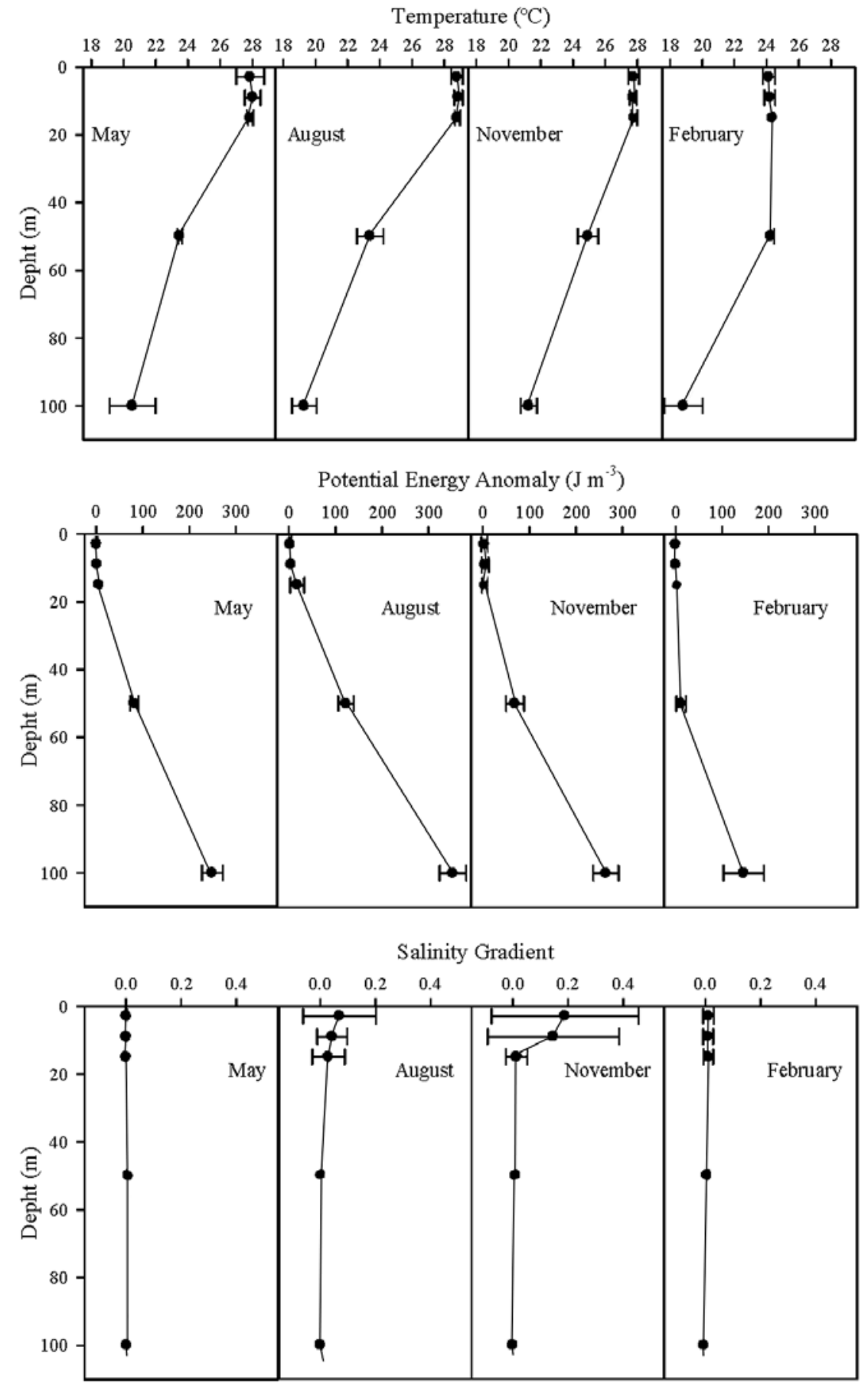

Figure 2

Average vertical distribution and standard deviation of temperature $\left({ }^{\circ} \mathrm{C}\right)$, potential energy anomaly $\left(\mathrm{J} \mathrm{m}^{-3}\right)$ and salinity gradient during the four sampling periods in the southern Gulf of Mexico

Distribución vertical del promedio y desviación estándar de la temperatura $\left({ }^{\circ} \mathrm{C}\right)$, anomalía de la energía potencial $\left(\mathrm{J}^{-3}\right)$ y gradiente de salinidad durante cuatro períodos de muestreo en el sur del Golfo de México 

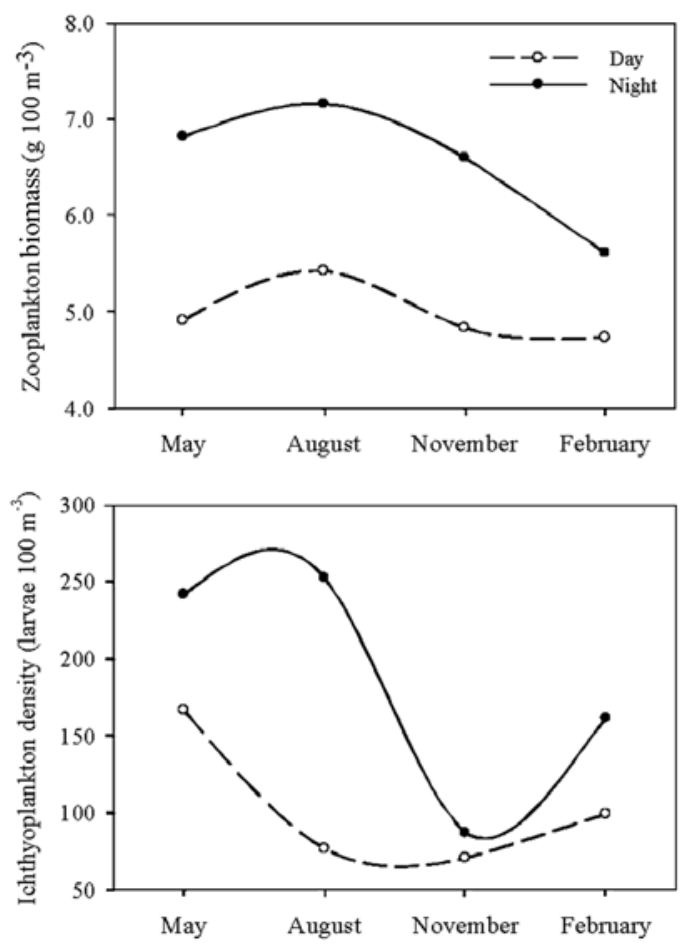

Figure 3

Day and night vertical distribution of seasonal average of zooplankton biomass $\left(\mathrm{g}^{\left.100 \mathrm{~m}^{-3}\right)}\right.$ and ichthyoplankton density (larvae $100 \mathrm{~m}^{-3}$ ) in the southern Gulf of Mexico

Distribución vertical del promedio estacional día y noche de

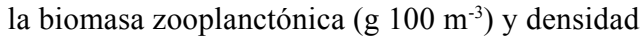
ictioplanctónica (larvas $100 \mathrm{~m}^{-3}$ ) en el sur del Golfo de

\section{México}

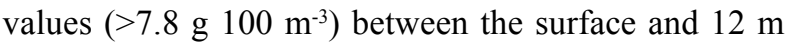
depth (Table 1). In February, the ZB distribution was relatively uniform during both the day and the night catches, from the surface to $50 \mathrm{~m}$ depth, with the lower values recorded at level 5 (Fig. 4). There were no statistical differences between the day and the night catches $(P>0.05)$.

Ichthyoplankton density presented significant differences $(P<0.05)$ between the day and night catches only in August and February. The highest ID occurred at night throughout the seasons, in the surface strata (0-18 $\mathrm{m})$ during May and August and in the deeper strata (50$100 \mathrm{~m}$ ) in November and February (Fig. 5, Table 1). The highest ichthyoplankton densities in these two last months were recorded in levels 4 and 5, and mostly included larvae from neritic families such as the Gobiidae, Engraulidae, Synodonthidae, Carangidae and Bregamacerotidae.

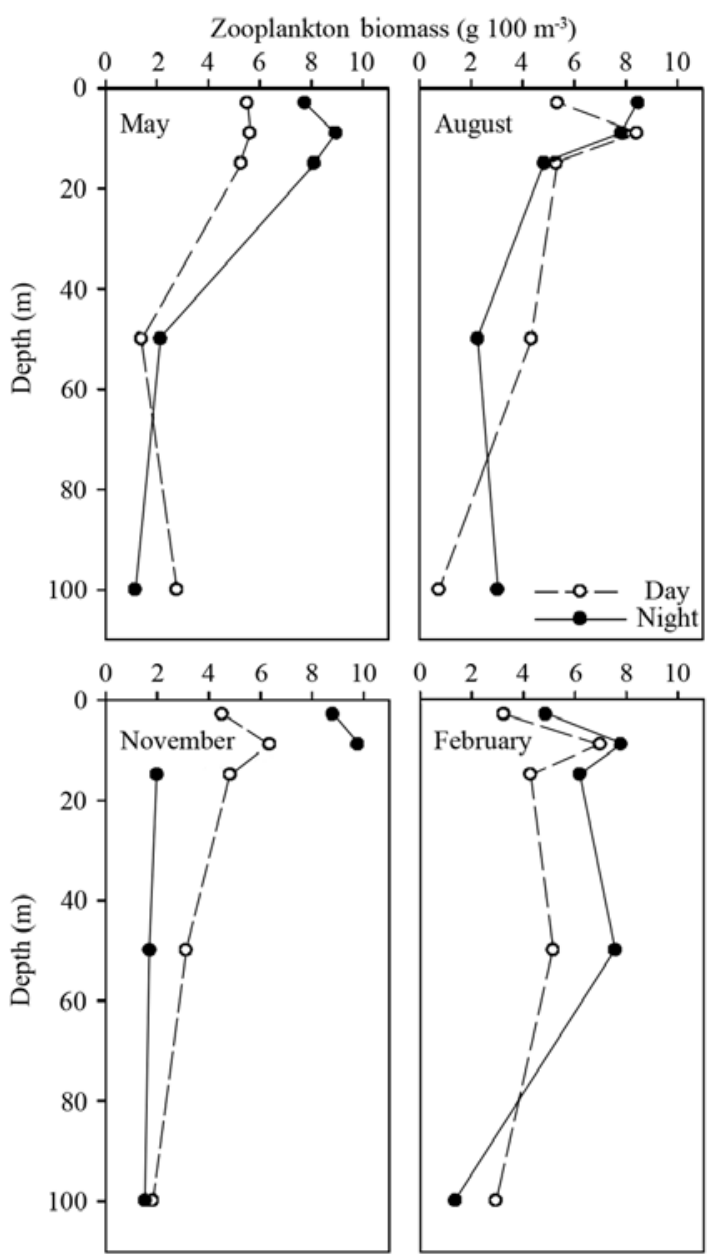

Figure 4

Vertical distribution of day and night average

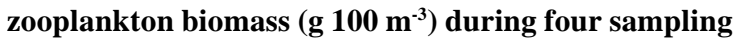
periods in the southern Gulf of Mexico

Distribución vertical del promedio de la biomasa

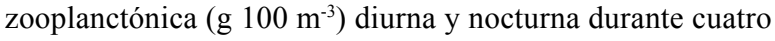
periodos de muestreo en el sur del Golfo de México

\section{Relationship between ZB and ID, and environmental parameters in the water column}

ANCOVA results showed a significant relationship $(P<0.05)$ between $\mathrm{ZB}$ and ID for all the study seasons (Table 2). The regression slopes between ZB and ID at each sampling level of the water column showed a positive relationship, with the exception of February at level 5 which had a negative relationship (Fig. 6). Although most of the relationships were positive, they were not all significant (Table 3 ). 
Table 1

Summary of statistics [mean \pm standard deviation (number of stations)] for day and night zooplankton biomass and ichthyoplankton density data by sampling level

Resumen estadístico [media \pm desviación estándar (número de estaciones)] de los datos de día y noche de la biomasa zooplanctónica y la densidad ictioplanctónica por nivel de muestreo

\begin{tabular}{|c|c|c|c|c|c|}
\hline \multirow{2}{*}{ Period } & \multirow{2}{*}{ Level } & \multicolumn{2}{|c|}{ Zooplankton biomass } & \multicolumn{2}{|c|}{ Ichthyoplankton density } \\
\hline & & Day & Night & Day & Night \\
\hline \multirow{5}{*}{ May } & 1 & $5.5 \pm 6.3 \quad(13)$ & $7.7 \pm 3.6$ & $226.3 \pm 250.8$ & $199.4 \pm 143.8(9)$ \\
\hline & 2 & $5.6 \pm 9.7 \quad(12)$ & $8.9 \pm 3.3$ & $209.0 \pm 259.5(12)$ & $289.6 \pm 247.2(9)$ \\
\hline & 3 & $5.2 \pm 5.2$ & $8.1 \pm 4.9$ & $137.9 \pm 169.2$ & $466.2 \pm 625.5(6)$ \\
\hline & 4 & $1.4 \pm 0.4$ & $2.1 \pm 0.7$ & $21.7 \pm 9.5$ & $46.3 \pm 45.2$ \\
\hline & 5 & $2.7 \pm 3.0$ & $1.1 \pm 0.8$ & $8.0 \pm 6.2$ & $36.6 \pm 51.6$ \\
\hline \multirow{5}{*}{ August } & 1 & $5.3 \pm 3.3$ & $8.4 \pm 3.4$ & $93.2 \pm 62.0(12)$ & $202.4 \pm 248.3$ \\
\hline & 2 & $8.4 \pm 6.9$ & $7.8 \pm 5.2$ & $111.0 \pm 122.2(12)$ & $581.5 \pm 458.0$ \\
\hline & 3 & $5.3 \pm 4.9$ & $4.8 \pm 0.0$ & $87.8 \pm 72.0(7)$ & --- \\
\hline & 4 & $4.3 \pm 2.3$ & $2.2 \pm 0.0$ & $33.8 \pm 18.5(6)$ & -- \\
\hline & 5 & $0.7 \pm 0.5$ & $3.0 \pm 0.0$ & $7.4 \pm 6.6$ & $\cdots$ \\
\hline \multirow{5}{*}{ November } & 1 & $4.5 \pm 4.4 \quad(13)$ & $8.8 \pm 9.6$ & $61.4 \pm 98.5(13)$ & $90.7 \pm 121.8(8)$ \\
\hline & 2 & $6.3 \pm 5.5$ & $9.7 \pm 17.4(5)$ & $87.6 \pm 93.7(13)$ & $111.2 \pm 190.2(5)$ \\
\hline & 3 & $4.8 \pm 5.1$ & $2.0 \pm 1.5$ & $96.0 \pm 87.0$ & $28.7 \pm 21.5$ \\
\hline & 4 & $3.1 \pm 2.5$ & $1.7 \pm 0.6$ & $45.3 \pm 26.4$ & $38.8 \pm 24.9$ \\
\hline & 5 & $1.8 \pm 0.6$ & $1.5 \pm 1.1$ & $17.6 \pm 12.2$ & $149.6 \pm 162.2(2)$ \\
\hline \multirow{5}{*}{ February } & 1 & $3.2 \pm 2.9 \quad(15)$ & $4.8 \pm 3.3 \quad(7)$ & $87.2 \pm 211.5(15)$ & $141.5 \pm 153.4(7)$ \\
\hline & 2 & $6.9 \pm 7.2 \quad(12)$ & $7.7 \pm 4.4 \quad(6)$ & $150.0 \pm 199.2(12)$ & $171.4 \pm 148.4(6)$ \\
\hline & 3 & $4.3 \pm 1.6$ & $6.2 \pm 4.4 \quad(6)$ & $92.6 \pm 70.3$ & $198.2 \pm 149.0(6)$ \\
\hline & 4 & $5.1 \pm 5.3$ & $7.5 \pm 5.7$ & $23.8 \pm 15.4$ & $245.0 \pm 181.3(5)$ \\
\hline & 5 & $2.9 \pm 1.0$ & $1.3 \pm 0.9$ & $20.1 \pm 19.1$ & $50.6 \pm 65.4$ \\
\hline
\end{tabular}

The MRA indicated that the environmental variables that determine the $\mathrm{ZB}$ and ID variability in the water column are different for each sampling season, and the GLM showed a significant relationship between ZB and ID and those variables. The multiple regression analysis applied to the data obtained in spring showed that the temperature and the mixing processes were the variables that determine the $\mathrm{ZB}$ and ID variability in the water column, with a $\mathrm{r}^{2}=0.59\left(\mathrm{~F}_{4,65}=23.12, \mathrm{~N}=20, P<0.01\right)$. The GLM indicated a significant relationship between ID and the environmental variables at the different sampling levels $\left(\mathrm{F}_{19,69}=5.59, P<0.01\right)$.

In summer, the vertical salinity gradient and mixing processes were the determinant variables for the $\mathrm{ZB}$ and ID distribution in the water column, with a $r^{2}=0.62$ $\left(F_{4,51}=20.46, \mathrm{~N}=56, P<0.01\right)$. The GLM made evident the significant relationship among water column components $\left(\mathrm{F}_{19,55}=4.40, P<0.01\right)$. In autumn, the temperature and vertical salinity gradient were the variables that presented a better relationship with the dependent variables $\left(\mathrm{F}_{24,59}=2.48, P<0.01\right)$ at the different sampling levels, with $\mathrm{a} \mathrm{r}^{2}=0.53\left(\mathrm{~F}_{5,54}=12.36, \mathrm{~N}=60, P<0.01\right)$. In winter, as in spring, the temperature and mixing processes were the variables with a better $\mathrm{ZB}$ and ID adjustment, with a $\mathrm{r}^{2}=0.27\left(\mathrm{~F}_{5,61}=4.52, \mathrm{~N}=67, P<0.01\right)$. The GLM results showed a significant relationship among variables and the ID $\left(\mathrm{F}_{24,66}=2.17, P<0.01\right)$. 

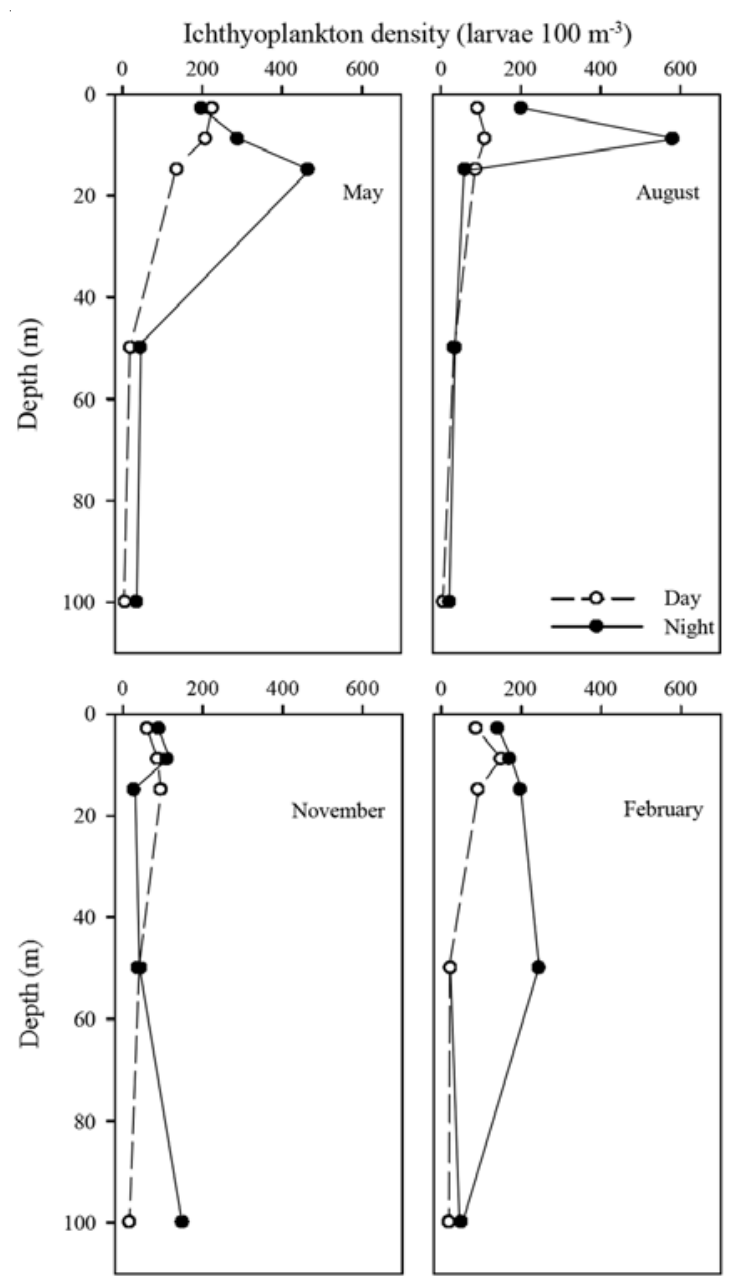

Figure 5

Vertical distribution of day and night average ichthyoplankton density (larvae $100 \mathrm{~m}^{-3}$ ) during four sampling periods in the southern Gulf of Mexico

Distribución vertical del promedio de la densidad ictioplanctónica (larvas $100 \mathrm{~m}^{-3}$ ) diurna y nocturna durante cuatro periodos de muestreo en el sur del Golfo de México

\section{Discussion}

\section{Vertical distribution pattern}

The vertical distribution of the ZB and ID throughout the seasons presented a similar pattern with the higher values in the surface layers and the lower values in the deeper strata, independently of the sampling hour. These results suggest that the water column in the study area can be divided into a 0 to $18 \mathrm{~m}$ surface layer and a 45 to $100 \mathrm{~m}$ deeper layer. The surface and deeper areas are usually inside and outside of the mixing layer respectively, except in February when the mixing layer reached a depth of $70 \mathrm{~m}$.

Similar patterns during the day have been found in other places. Sabatés (2004) and Comyns \& LyczkowskiShultz (2004) recorded the highest larval fish densities at the surface where food availability was greatest.

The surface layer of the water column has been considered the most productive, where food particles exist in high concentrations. This is therefore the most important stratum for trophic interactions (Coombs et al. 1994, Gray \& Kingsford 2003).

Additionally, the high ZB and ID values recorded in the mixed layer must be related to higher concentrations of chlorophyll a (Zeldis et al. 1995). Accordingly, the areas of greatest chlorophyll $a$ richness in the southern Gulf of Mexico are located between the surface and 40 $\mathrm{m}$ depth, with a maximum concentration at $10 \mathrm{~m}$ (Licea \& Luna 1999, Aguirre-Gómez 2002). The location of this maximum peak of chlorophyll $a$ agrees with the depth (6-12 $\mathrm{m})$ at which the highest values of ZB and ID were recorded.

Several studies have associated the vertical distribution of zooplankton and ichthyoplankton with the location of the maximum chlorophyll $a$ concentration layer. Sameoto (1984), Townsend et al. (1984) and Harris (1988) hypothesized that the location of the maximum chlorophyll $a$ concentration is an important factor in the behaviour of zooplankton that determines the vertical distribution of different stages in the water column.

On the other hand, in February the wind-induced mixing generated a homogeneous distribution of $\mathrm{ZB}$ and ID from the surface to a depth of $70 \mathrm{~m}$. The mixing of the surface layer of the water column tends to prevent the formation of plankton patches and allows a uniform distribution (Okubo \& Levin 2001) that favours the vertical distribution of zooplankton throughout the water column (Checkley et al. 1992, Farstey et al. 2002). When data were analysed separately for day and night, for the November and February data, the pattern broke and a higher ID was recorded at levels 5 and 4 respectively. The high concentration observed in February may be attributed to the organisms having a better distribution throughout the water column under mixed conditions (Combs et al. 1992).

\section{Relationship between ZB and ID}

Zooplankton and ichthyoplankton present different types of relationships in the pelagic environment. These may be positive, negative and random, and are visible at 

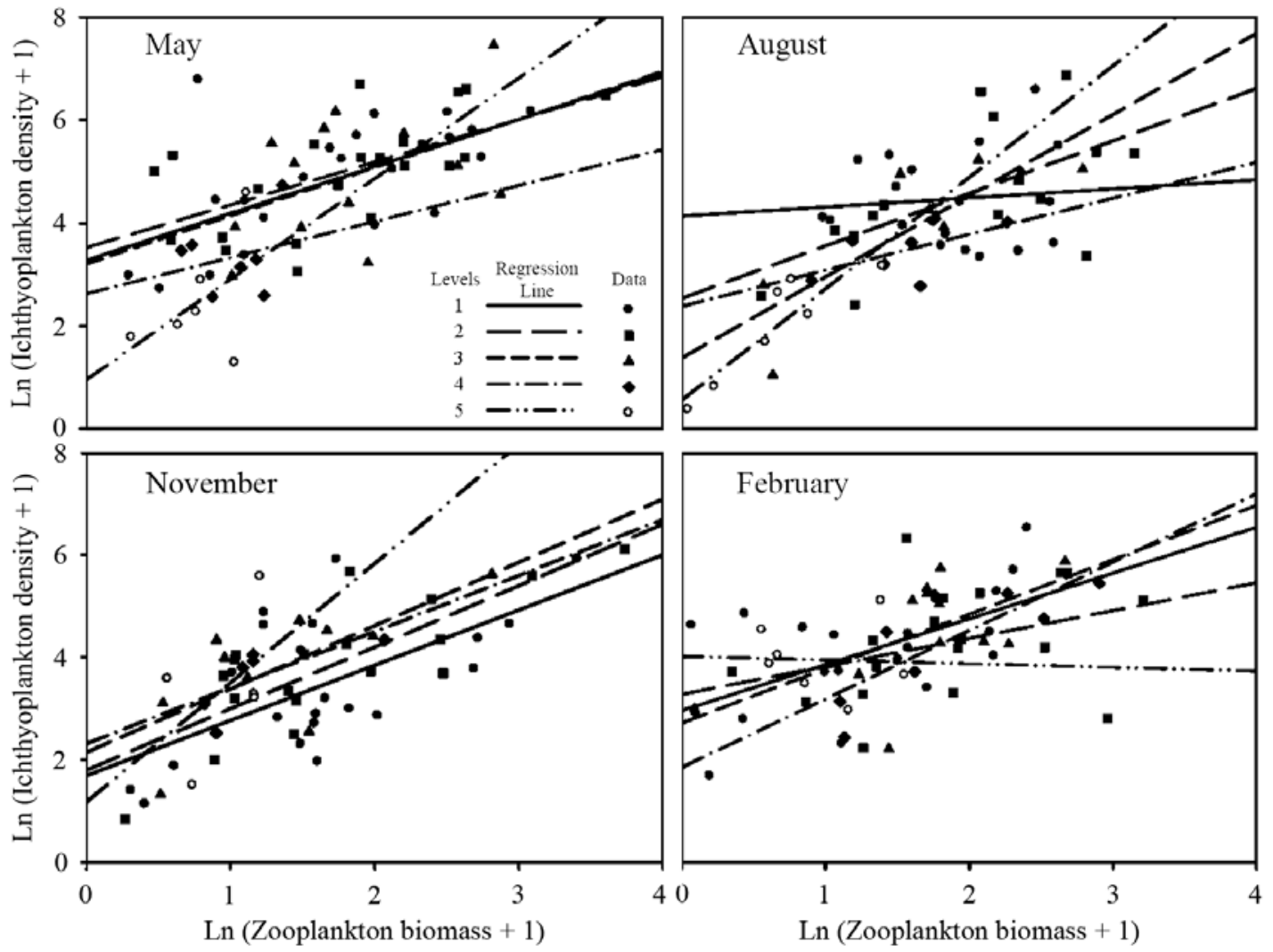

Figure 6

\section{Relationship between zooplankton biomass and ichthyoplankton density at different levels of the water column during the four sampling periods}

Relación entre la biomasa zooplanctónica y densidad ictioplanctónica a diferentes niveles de la columna de agua durante los cuatro periodos de muestreo

different temporal and spatial scales.

The trophic dependency of ichthyoplankton on zooplankton is unquestionable and results in a positive relationship that is not necessarily statistically significant. The relationship may fluctuate from positive to negative (Sanvicente-Añorve et al. 2006). There are several factors that generate a positive relationship between fish larvae and zooplankton. Among these, one may mention the composition of zooplankton that allows the survival of fish larvae, that is to say, that big zooplankton predators such as chaetognaths, ctenophores and jellyfish are absent or in low numbers in such a way that the type and size of zooplankton is adequate enough for the consumption of larvae (Loeb 1979, Cowan \& Shaw 1991, SanvicenteAñorve et al. 2006). Considering that zooplankton organisms represent the main food resource of fish larvae, it is important that both be present at the same time and in the same place (Cushing 1975). Fortier \& Harris (1989) declared that positive patterns are a consequence of a density-dependent competition, and that ontogenetic migration of fish postlarvae is the result of a progressive adjustment of their vertical distribution to the vertical distribution of their prey.

In this study, the relationship between ZB and ID is considered to be a predator-prey relationship, although not necessarily direct, as the zooplankton biomass net used was a $505 \mu \mathrm{m}$ mesh that collects organisms bigger than the food items of fish larvae. Nevertheless, it is assumed that the zooplankton biomass represents the size level in the trophic chain that is sustained by smaller organisms, such as the nauplii larvae of crustaceans and the copepodite stages of the dominant zooplanktonic groups. 
Table 2

ANCOVA results for different sampling periods (ichthyoplankton density = dependent variable)

Resultados del ANCOVA en diferentes periodos de muestreo (Densidad ictioplanctónica = Variable dependiente)

\begin{tabular}{|c|c|c|c|c|c|c|}
\hline Period & Variables & Df & $\begin{array}{l}\text { Sum of } \\
\text { Squares }\end{array}$ & $\begin{array}{c}\text { Mean } \\
\text { Square }\end{array}$ & F-Ratio & $P$-Value \\
\hline \multirow{4}{*}{ May } & Level & 4 & 3.58 & 0.89 & 0.96 & 0.43 \\
\hline & Zooplankton biomass & 1 & 5.49 & 5.49 & 5.91 & 0.01 \\
\hline & Level * Zooplankton biomass & 4 & 0.54 & 0.13 & 0.15 & 0.96 \\
\hline & Residual & 59 & 54.93 & 0.93 & & \\
\hline \multirow{4}{*}{ August } & Level & 4 & 10.94 & 2.73 & 3.44 & 0.01 \\
\hline & Zooplankton biomass & 1 & 13.68 & 13.68 & 17.2 & 0.00 \\
\hline & Level * Zooplankton biomass & 4 & 6.22 & 1.55 & 1.95 & 0.11 \\
\hline & Residual & 46 & 36.61 & 0.79 & & \\
\hline \multirow{4}{*}{ November } & Level & 4 & 0.56 & 0.14 & 0.15 & 0.96 \\
\hline & Zooplankton biomass & 1 & 11.40 & 11.40 & 11.88 & 0.00 \\
\hline & Level * Zooplankton biomass & 4 & 0.61 & 0.15 & 0.16 & 0.95 \\
\hline & Residual & 50 & 48.01 & 0.96 & & \\
\hline \multirow{4}{*}{ February } & Level & 4 & 2.26 & 0.56 & 0.47 & 0.76 \\
\hline & Zooplankton biomass & 1 & 6.84 & 6.84 & 5.62 & 0.02 \\
\hline & Level * Zooplankton biomass & 4 & 2.62 & 0.65 & 0.54 & 0.70 \\
\hline & Residual & 57 & 69.43 & 1.21 & & \\
\hline
\end{tabular}

Table 3

Regression model values, correlation ( $r$ ) and significance level of the relationships between zooplankton biomass and ichthyoplankton density at different levels of the water column during the four sampling periods

Valores del modelo de regresión, correlación (r) y nivel de significancia de las relaciones entre la biomasa zooplanctónicas y la densidad ictioplanctónica a diferentes niveles de la columna de agua durante los cuatro periodos de muestreo

\begin{tabular}{|c|c|c|c|c|c|c|}
\hline Period & Level & Slope & Ordinate & $\mathbf{r}$ & $P$-Value & $\begin{array}{c}\text { Significance } \\
\text { Level }(P<0.05)\end{array}$ \\
\hline \multirow{5}{*}{ May } & 1 & 0.912 & 3.276 & 0.623 & 0.002 & Yes \\
\hline & 2 & 0.831 & 3.519 & 0.616 & 0.003 & Yes \\
\hline & 3 & 0.936 & 3.202 & 0.465 & 0.110 & No \\
\hline & 4 & 0.701 & 2.625 & 0.254 & 0.583 & No \\
\hline & 5 & 1.950 & 0.954 & 0.482 & 0.333 & No \\
\hline \multirow{5}{*}{ August } & 1 & 0.176 & 4.134 & 0.102 & 0.679 & No \\
\hline & 2 & 1.020 & 2.533 & 0.608 & 0.016 & Yes \\
\hline & 3 & 1.578 & 1.377 & 0.821 & 0.012 & Yes \\
\hline & 4 & 0.700 & 2.376 & 0.589 & 0.164 & No \\
\hline & 5 & 2.167 & 0.556 & 0.502 & 0.006 & No \\
\hline \multirow{5}{*}{ November } & 1 & 1.078 & 1.691 & 0.624 & 0.003 & Yes \\
\hline & 2 & 1.200 & 1.799 & 0.792 & 0.000 & Yes \\
\hline & 3 & 1.236 & 2.145 & 0.708 & 0.022 & Yes \\
\hline & 4 & 1.094 & 2.314 & 0.721 & 0.106 & No \\
\hline & 5 & 2.327 & 1.176 & 0.476 & 0.418 & No \\
\hline \multirow{5}{*}{ February } & 1 & 0.642 & 3.086 & 0.340 & 0.122 & No \\
\hline & 2 & 0.545 & 3.279 & 0.368 & 0.133 & No \\
\hline & 3 & 1.063 & 2.719 & 0.598 & 0.040 & Yes \\
\hline & 4 & 1.337 & 1.848 & 0.802 & 0.017 & Yes \\
\hline & 5 & -0.071 & 4.019 & $=0.040$ & 0.932 & No \\
\hline
\end{tabular}


The positive relationship observed in the study area emerges as a consistent pattern in space and time, probably as a consequence of the continuous production cycle in the southern Gulf of Mexico. This suggests that zooplankton and ichthyoplankton are always present, and this guarantees the availability of food throughout the year, as well as the uninterrupted generation of growth and reproduction of organisms. With respect to this, Harden-Jones (1968) mentioned that eggs, larvae, juveniles and adult fish may remain together in tropical areas where production is continuous and food is always available.

\section{Physical parameters that influence the ZB-ID relationship}

The multiple regression analysis showed that the temperature, the vertical salinity gradient and the mixing processes were the most constant factors influencing the variability of the distribution of $\mathrm{ZB}$ and ID throughout the annual cycle, and the GLM indicated there is a significant relationship among the water column components. Nevertheless, the existence of two layers, a mixed surface layer and a deeper stratified layer, seems to be an established distribution pattern in the water column in the study area.

In February and May, the main factors influencing the relationship between $\mathrm{ZB}$ and ID were the temperature and the mixing process. In February, although the relationship between the $\mathrm{ZB}$ and ID was positive for all the surface levels, these were not all significant. The highest correlation values were obtained for levels 3 and 4 , resulting from the mixing process that transports zooplankton organisms into the deeper layers. Fish larvae and other zooplankton species were seen to avoid the turbulent strata by swimming or sinking in the water column, as well as to increase their concentration and the predator-prey encounter rate (Franks 2001, Incze 2001, Pringle 2007) that may favour the feeding of zooplankton (Rothschild \& Osborn 1988). As the deep layer $(50-100 \mathrm{~m})$ is not affected by the mixing processes, a high concentration of organisms impacting on the trophic interactions may be expected.

The only negative value for the ZB and ID relationship was recorded during the winter in level 5, possibly as the result of the exhaustion of zooplankton by ichthyoplankton (Sanvicente-Añorve et al. 2006).

The most important factor during August and November was the vertical salinity gradient, as it is during these periods that continental water discharges are the strongest (IMTA 2000) and affect the surface strata (0$12 \mathrm{~m})$. The ZB and ID relationship was positive and generally significant in the upper layers during these periods, indicating that feeding conditions were convenient for both components.

Areas associated with large rivers, like the GrijalvaUsumacinta system and others in the region, usually present a highly biological production in surface waters as a result of the discharge of nutrient-rich river water that favours carbon fixation by phytoplankton and, in turn, high concentrations of zooplankton (Dagg et al. 2004, Dagg \& Brown 2005). In addition, Cowan \& Shaw (1991) established that river water discharges over the inner continental shelf may have an important effect on the ZB and ID relationship, generating a high turbulence and intensifying the number of contacts between predators and prey (Lewis \& Padley 2001).

\section{Acknowledgments}

We express our thanks to Dirección General del Personal Académico of the Universidad Nacional Autónoma de México for support of this study through Programmes IN-202092 and IN-203893, as well as the anonymous reviewers for their comments to the manuscript.

\section{Literature cited}

Aguirre-Gómez R. 2002. Primary production in the southern Gulf of Mexico estimated from solar-stimulated natural fluorescence. Hidrobiologica 12: 21-28.

Ahlstrom EH. 1959. Vertical distribution of pelagic fish eggs and larvae off California and Baja California. U.S. Fish Wildlife Service. Fishery Bulletin 60: 107-146.

Boehlert GW \& BC Mundy. 1994. Vertical and onshoreoffshore distributional patterns of tuna larvae in relation to physical habitat features. Marine Ecology Progress Series 107: 1-13.

Checkley DM Jr, S Uye, MJ Dagg, MM Mullin, M Omori, T Onbe \& MY Zhu. 1992. Diel variation of the zooplankton and its environment at neritic stations in the inland Sea of Japan and the north-west Gulf of Mexico. Journal of Plankton Research 14: 1-40.

Comyns BH \& J Lyczkowski-Shultz. 2004. Diel vertical distribution of atlantic croaker, Micropogonias undulatus, larvae in the northcentral Gulf of Mexico with comparisons with red drum Sciaenops ocellatus. Bulletin of Marine Science 74: 69-80.

Coombs SH, JH Nichols, DVP Conway, S Milligan \& NC Halliday. 1992. Food availability for sprat larvae in the Irish Sea. Journal of the Marine Biological Association of the United Kingdom 72: 821-834.

Coombs SH, DB Robins, DVP Conway, NC Halliday \& AJ Pomroy. 1994. Suspended particulates in the Irish Sea and feeding conditions for fish larvae. Marine Biology 118: 715. 
Cowan JH \& RF Shaw. 1991. Ichthyoplankton off west Louisiana in winter 1981-1982 and its relationship with zooplankton biomass. Contributions in Marine Science 32: 103-121.

Cushing DH 1975. Marine ecology and fisheries, $278 \mathrm{pp.}$ Cambridge University Press, Cambridge.

Dagg MJ \& SL Brown. 2005. The potential distribution of fecal pellets from the larvacean Oikopleura dioica to vertical flux of carbon in a river dominated coastal margin. In: Gorsky G, MJ Youngbluth \& D Diebel (eds). Response of marine ecosystems to global change. Ecological impact of appendicularians, pp. 293-307. Contemporary Publishing International. Paris.

Dagg MJ, R Benner, S Lohrenz \& D Lawrence. 2004. Transformation of dissolved and particulate materials on continental shelves influenced by large rivers, plume processes. Continental Shelf Research 24: 833-858.

Davis TL, GP Jenkins \& JW Young. 1990. Diel patterns of vertical distribution in larvae of southern bluefin Thunnus maccoyii, and other tuna in the East Indian. Marine Ecology Progress Series 59: 63-74.

Espinosa-Fuentes ML \& C Flores-Coto. 2004. Cross-shelf and vertical structure of ichthyoplankton assemblages in continental shelf waters of the southern Gulf of Mexico. Estuarine Coastal and Shelf Science 59: 333-352.

Farstey V, B Lazar \& A Genin. 2002. Expansion and homogeneity of the vertical distribution of zooplankton in a very deep mixed layer. Marine Ecology Progress Series 91: 91-100.

Flores-Coto C \& U Ordóñez-López. 1991. Larval distribution and abundance of Myctophidae, Gonostomatidae and Sternoptychidae from the southern Gulf of Mexico. In: Hoyt RD (ed). Larval fish recruitment and research in the Americas. Proceedings of the thirteenth annual fish conference, 21-26 May 1989, Mérida, México. NOAA Technical Report NMFS 95: 55-64.

Flores-Coto C, L Sanvicente-Añorve, R Pineda-López \& MA Rodríguez-van Lier. 1988. Composición, distribución y abundancia ictioplanctónica en el sur del Golfo de México. Universidad y Ciencia 5: 65-84.

Flores-Coto C, F Zavala-García \& G Espinosa-Villagrán. 1993. Asociaciones ictioplactónicas de la Bahía de Campeche, México (verano 1987). Facultad de Ciencias del Mar, Universidad Católica del Norte, Coquimbo, Chile. Serie Ocasional 2: 57-67.

Flores-Coto C, P Figueroa-Páez \& F Zavala-García. 1999. Distribución y abundancia de larvas de Sciaenidae en la columna de agua, en el sur del Golfo de México. Primavera. Hidrobiologica 9: 135-144.

Flores-Coto C, R Martínez-Gutiérrez, M González-Félix, L Sanvicente-Añorve \& F Zavala-García. 2000. Annual variation of ichthyoplankton assemblages in neritic waters of the southern Gulf of Mexico. Caribbean Journal of Science 36: 233-243.
Flores-Coto C, R Rivas-Vega, F Zavala-García \& J SánchezRobles. 2001. Vertical distribution of larval carangids in the southern Gulf of Mexico. Gulf Caribbean Research 13: $1-8$.

Fortier L \& RP Harris. 1989. Optimal foraging and densitydependent competition in marine fish larvae. Marine Ecology Progress Series 51: 19-33.

Franks PJS. 2001. Turbulence avoidance: An alternate explanation of turbulence-enhanced ingestion rates in the field. Limnology and Oceanography 46: 959-963.

Gasca R, E Suárez \& I Castellanos. 1995. Biomasas zoopláncticas en aguas superficiales del Golfo de México durante verano e invierno de 1991. Caribbean Journal of Science 31: 128-140.

Gray AC \& MJ Kingsford. 2003. Variability in thermocline depth and strength, and relationships with vertical distributions of fish larvae and mesozooplankton in dynamic coastal waters. Marine Ecology Progress Series 247: 211224.

Harden-Jones FR. 1968. Fish migration, 325 pp. Edward Arnold, London.

Harris RP. 1988. Interactions between diel vertical migratory behavior of marine zooplankton and the subsurface chlorophyll maximum. Bulletin of Marine Science 43: 663674.

IMTA. 2000. Banco Nacional de Datos de Aguas Superficiales (BANDAS). 7 CDS. Secretaría del Medio Ambiente y Recursos Naturales, Comisión Nacional del Agua, Instituto Mexicano de Tecnología del Agua, Jiutepec, Morelos. México. [CD-ROM].

Incze LS, D Hebert, N Wolff, N Oakey \& D Dye. 2001. Changes in copepod distributions associated with increased turbulence from wind stress. Marine Ecology Progress Series 213: 229-240.

Levene H. 1960. Robust test for equality of variance. In: Olkin Z (ed). Contributions to probability and statistics, pp. 278292. Stanford University Press, Palo Alto.

Lewis DM \& TJ Padley. 2001. The influence of turbulence on plankton predation strategies. Journal of Theoretical Biology 210: 347-356.

Licea S \& R Luna. 1999. Spatio-temporal variation of phytoplankton on the continental margin in the SW Gulf of Mexico. Revista de la Sociedad Mexicana de Historia Natural 49: 83-99.

Loeb VJ. 1979. Larval fishes in the zooplankton community of the North Pacific Central Gyre. Marine Biology 53: 173191.

Loeb VJ \& JA Nichols. 1984. Vertical distribution and composition of ichthyoplankton and invertebrate zooplankton assemblages in the Eastern Tropical Pacific. Biología Pesquera 13: 39-66.

Munk P, T Kiorbe \& V Christensen. 1989. Vertical migrations of herring, Clupea harengus, larvae in relation to light and prey distribution. Environmental Biology of Fish 26: 8796. 
Okubo A \& SA Levin. 2001. Diffusion and ecological problems. Modern perspectives, 373 pp. Springer, New York.

Pringle JM. 2007. Turbulence avoidance and the wind-driven transport of plankton in the surface Ekman layer. Continental Shelf Research 27: 670-678.

Rothschild B \& T Osborn. 1988. Small-scale turbulence and plankton contact rates. Journal of Plankton Research 10: 465-474.

Sabatés A. 2004. Diel vertical distribution of fish larvae during the winter-mixing period in the northwestern Mediterranean. ICES Journal of Marine Science 61: 12431252.

Salas-de-León D, A Monreal-Gómez, L Sanvicente-Añorve \& C Flores-Coto. 1998. Influence de la circulation à long terme sur la distribution des organismes zooplanctoniques dans la Baie de Campeche, Mexique. Oceanological Acta 21: 87-93.

Sameoto DD. 1984. Environmental factors influencing diurnal distribution of zooplankton and ichthyoplankton. Journal of Plankton Research 6: 767-792.

Sanvicente-Añorve L, C Flores-Coto \& L Sánchez-Velasco. 1998. Spatial and seasonal patterns of larval fish assemblages in the southern Gulf of Mexico. Bulletin of Marine Science 62: 17-30.
Sanvicente-Añorve L, LA Soto, ML Espinosa-Fuentes \& C Flores-Coto. 2006. Relationship patterns between ichthyoplankton and zooplankton: a conceptual model. Hydrobiologia 559: 11-22.

Sclafani M, CT Taggart \& KR Thompson. 1993. Condition, buoyancy and the distribution of larval fish -implications of vertical migration and retention. Journal of Plankton Research 15: 413-435.

Simpson JH, CM Allen \& NCG Morris. 1978. Fronts on the continental shelf. Journal of Geophysical Research 28A C9: 4607-4614.

Townsend DW, TL Cucci \& T Berman. 1984. Surface chlorophyll maxima and vertical distribution of zooplankton in the Gulf of Maine. Journal of Plankton Research 6: 793-802.

Zar JH. 1996. Biostatistical analysis, 662 pp. Prentice Hall, Englewodd Cliffs.

Zavala-García F \& C Flores-Coto. 1989. Medición de biomasa zooplanctónica. Anales del Instituto de Ciencias del Mar y Limnología, UNAM 16: 273-278.

Zeldis JR, CS Davis, MR James, SL Ballara, WE Booth \& FH Chang. 1995. Salp grazing: effects on phytoplankton abundance, vertical distribution and taxonomic composition in a coastal habitat. Marine Ecology Progress Series 126: 267-283.

Recibido el 10 de octubre de 2008 y aceptado el 10 de junio de 2009 